Article

\title{
Exploring the Relationship between River Discharge and Coastal Erosion: An Integrated Approach Applied to the Pisa Coastal Plain (Italy)
}

\author{
Monica Bini ${ }^{1, *(D)}$, Nicola Casarosa ${ }^{2}$ and Marco Luppichini ${ }^{1,3}$ (D) \\ 1 Department of Earth Sciences, University of Pisa, Via S. Maria, 52, 56126 Pisa, Italy; marco.luppichini@unifi.it \\ 2 Consorzio di Bonifica C4 BassoValdarno, 56125 Pisa, Italy; nicola.casarosa@c4bassovaldarno.it \\ 3 Department of Earth Sciences, University of Study of Florence, Via La Pira 4, 50121 Florence, Italy \\ * Correspondence: monica.bini@unipi.it
}

check for

updates

Citation: Bini, M.; Casarosa, N.; Luppichini, M. Exploring the Relationship between River Discharge and Coastal Erosion: An Integrated Approach Applied to the Pisa Coastal Plain (Italy). Remote Sens. 2021, 13, 226. https://doi.org/10.3390/ rs13020226

Received: 21 December 2020 Accepted: 8 January 2021 Published: 11 January 2021

Publisher's Note: MDPI stays neutral with regard to jurisdictional clai$\mathrm{ms}$ in published maps and institutional affiliations.

Copyright: $(2021$ by the authors. Licensee MDPI, Basel, Switzerland. This article is an open access article distributed under the terms and conditions of the Creative Commons Attribution (CC BY) license (https:// creativecommons.org/licenses/by/ $4.0 /)$.

\begin{abstract}
Coastal erosion coupled with human-induced pressure has severely affected the coastal areas of the Mediterranean region in the past and continues to do so with increasing intensity today. In this context, the Pisa coastal plain shows a long history of erosion, which started at the beginning of the nineteenth century. In this work, shoreline positions derived from historical maps as well as airborne and DGPS (Differential Global Positioning System) surveys were analyzed in a GIS (Geographic Information System) environment to identify the main changes that have occurred in the last 142 years. These analyses were compared with 100 years of discharge data measured at the S. Giovanni alla Vena gauge to identify a possible correlation between the two sets of information. Finally, Sentinel-2 and Landsat images were studied to identify the dispersion of sediments transported by the Arno River. In particular, we found a minimum of fluvial discharge in the years 1954, 1978, and 2012 corresponding to a peak of erosion, while the reduced erosion rate and the fluvial discharge increased in the years 1928-1944, 1954-1975, and after 2012. The qualitative anticorrelation between discharge and erosion is particularly true if we take into account flood events with a value of discharge greater than $700 \mathrm{~m}^{3} / \mathrm{s}$, which are those able to transport suspended sand. The remote sensing analyses of Sentinel-2 images acquired during the floods of 6 February 2019 and 3 December 2019, under the most typical wind and sea state conditions for this area (wind coming from SW and storms coming from W/SW and SW) show that during these events a consistent amount of sediment was transported by the river. However, the majority of these sediments are not deposited along the coastline but are dispersed offshore. Grain-size analyses on the transported sediment show that plumes are formed by coarse-to-medium sand, suitable for coastal nourishment, but the reconstructed sediment dispersion lines show that some sectors of the coastline are constantly in the shade. These areas are the most affected by erosion.
\end{abstract}

Keywords: coastal erosion; coastal environmental monitoring; remote sense monitoring; Pisa coastal plain; Arno River

\section{Introduction}

In the last decades coastal erosion has become one of the main environmental threats worldwide [1-4]. Approximately $28,000 \mathrm{~km}^{2}$ of the global coastline was eroded between 1984 and 2015 and about twice as many as those formed by accumulation processes [5]. According to the Fifth Assessment Report of the Intergovernmental Panel on Climate Change (IPCC) [6] the foreseen future scenario for coastal zones will worsen as a result of the gradual rise in sea level and of the possible increase of extreme events due to global warming linked to the use of fossil fuels and human pressure [6]. Specifically, the Mediterranean region is severely affected by the impact of extreme climatic events (e.g., storm surges) coupled with human-induced pressures (e.g., poorly planned buildings on the coast, dam construction, land use changes inland), resulting in growing vulnerability 
of the coastal areas [7]. In these areas, the number of coexisting socio-economic activities (urbanization, tourism, natural protected areas) makes it imperative to understand and further monitor coastal dynamics [8-11]. The change in land cover dynamics is considered one of the most important variables of global change affecting the coastal systems, especially for the effects on river sediment supply [12-14]. A decrease in solid load documented for several river-systems of the Mediterranean basin (e.g., Nile, Ebro, Rhône), in particular after the 1970s [8,14-16], has been considered one of the dominant causes of coastal erosion, together with subsidence and sea level rise [9,17-19].

Despite the importance of a correct estimation of solid load, for many Mediterranean rivers solid load measurements are inadequate, probably because they are cost- and timeconsuming. For these reasons the contribution of solid load in countering coast erosion is largely speculative. Even fewer data are available regarding the dynamics of long-shore and off-shore dispersion of sediments carried by rivers, which is another key point for the understanding of coastal erosion dynamics.

Thanks to the availability of a long series of data that make it possible to better understand the current evolution and to predict future trends, in this paper we propose an integrated approach to the study of coastal erosion along the Pisa coastal plain (central Italy). This area has been affected by marked erosive coastal processes since the late nineteenth century (1850-1870) [8,20-26]. Here, the temporal evolution of erosion and the possible effects of the construction of anthropogenic defenses have been extensively studied $[22,27,28]$, while the primary causes of this phenomenon have been less analyzed.

Our proposed replicable approach-based on a strong integration of data coming from the analysis of shoreline position, river discharge and sediment dispersion, applied to the study of the Pisa coastal plain - could also be applied to other coastal areas affected by coastal erosion. This would provide guidance on some basic elements that need to be taken into account and on appropriate planning choices necessary for the protection of the territory.

\section{Study Area}

The Pisa coastal plain has been progressively shaped by the Arno river since the Late Holocene [29-32] (Figure 1a,c-e). In this area SW winds have the highest frequency in each velocity range, while NW winds are frequent but subordinate to the former [33]. Major storm events come from W/SW and SW, even if high energy events can also be related to NW winds [33]. Detailed analyses [34] show that more than $90 \%$ of storms (on average 48 events per year) originate in the $220-260^{\circ} \mathrm{N}$ sector, while less than three events per year generally occur in the $210-180^{\circ} \mathrm{N}$ sector. Finally, only less than one event per year comes from the other sectors (Figure 1b) [34]. In the coastal sector located in the hydrographic left of the Arno River the littoral drift is mainly oriented towards the south, with the exception of the area between Calambrone and the Scolmatore Channel, where the littoral drift is oriented towards the north. Conversely, in the coastal sector located in the hydrographic right, the littoral drift is oriented towards the north [11,30] (Figure 1c,d). The coast experiences a microtidal regime, where the spring tide is only $\mathrm{ca} .30 \mathrm{~cm}$ [35].

The coastal plain studied has been affected by a prolonged period of coastal erosion [8,20-26]. This process is thought to be mainly linked to anthropogenic activities (riverbed dredging, mountain reforestation, diffused riverbed reinforcement, river barriers), which have caused a drastic decrease in the sedimentary load of the Arno river [11,33]. Some key areas for the local touristic economy have been particularly affected by erosion (area A in Figure $1 \mathrm{~d}$ and area B in Figure 1e). In these two areas, separated from the mouth of the Arno river with its engineering structures built in 1926, the local authorities have applied different approaches in the management of the territory. Specifically, the Area A located in the Migliarino San Rossore Massaciuccoli Natural Park, characterized by a highly natural environment and few anthropogenic structures, was allowed to evolve without the construction of coastal protection structures until 2001. The only exception was five detached breakwaters, built between 1962 and 1968 to defend il Gombo beach. Here, in 1984, after limited results, four out of five breakwaters were elevated and extended, resulting in the formation of tombolos [28]. More recently (2001 and 2003), 10 emerged groins with submerged extensions were 
built between il Gombo beach and the Arno River mouth [27,28,34]. In 2009 an artificial tombolo was constructed to connect the fourth breakwater and two submerged groins. These last structures were quickly destroyed by coastal erosion [28].

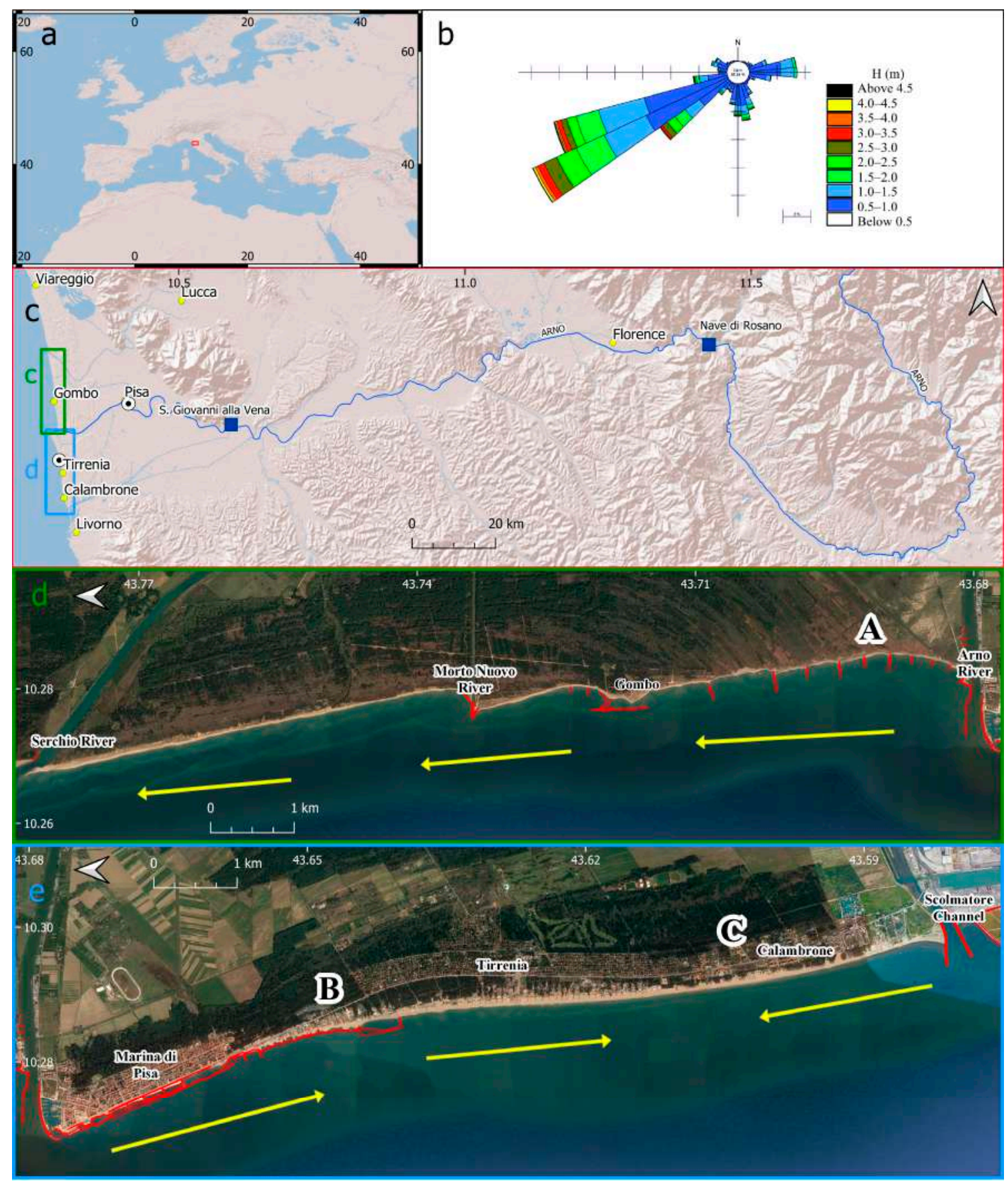

Figure 1. A, B and C indicate specific coastal stretches to which reference has been made in the text. Location map of the study area (a,c-e); (b) directional analysis of wave data (https:/ / www.cfr.toscana.it/index.php?IDS=42\&IDSS=282) recorded at the Gorgona Buoy $(43.57 \mathrm{~N}$; 9.95E) grouped by average direction of origin and by height wave classes, data between 1 October 2008 and 1 May 2012 (modified after [34]); (c) Arno River course (blue line), discharge gauges (blue squares), location of samples used for grain-size analyses (black and white dots); (d,e) northern and southern sectors respectively of the study area. Yellow arrows indicate the littoral drift direction [11,22]), the red line indicates the coastal defense structures. 
The area B, characterized by the presence of the Marina di Pisa village (founded around 1872), and of tourist facilities and seaside settlements, has been constantly subjected to anthropogenic interventions aimed at mitigating the erosion $[35,36]$. In this sector, the battle against erosion started in the early twentieth century [28], as documented by the construction of perishable structures designed to protect the beach in front of the recently built settlement of Marina di Pisa [28], which led to the construction of a complex defense system. Before 1928 several short groins were constructed along the first kilometer southward of the river mouth $[27,28]$. Later, a detached breakwater was constructed and connected to an older groin [28]. Before 1954 another breakwater was constructed, making the first kilometer of coastline totally artificial. A further improvement in defense construction is observed in the following years. Specifically, 10 detached breakwaters were constructed, some of which were connected to the coast with groins [27,34,37] (Figure 1d).

In this way the shoreline position was fixed but erosion continued on the submerged profile [28]. Up until now, the structures have been modified in different ways and recently four of the ten breakwaters have been converted into submerged structures. In the last years, without a general development project, the construction of shoreline protection has undergone a southward migration towards the village of Tirrenia, in order to maintain the touristic potential of the beach. However, the touristic value of this coast has been strongly reduced, as documented by [28]. In the last 20 years this area has received several artificial nourishments [38,39]. This different evolution of sectors A and B has determined the asymmetrical development of the Arno river delta [27]. Coastal erosion is still active in both sectors, despite the major efforts to counter this process [22,24,34].

\section{Materials and Methods}

The changes in the coastline position of the Pisa coastal plain were studied for a chronological interval of 142 years (data from 1878 to 2020) by using a heterogeneous database consisting of topographic maps, airborne images and DGPS (Differential Global Position System) measurements (Table 1). The data were managed using the open source QGIS 3.10 software. A linear shapefile with the position of the shoreline (derived by manual operator delimitation and digitalization) was created for each analyzed year until 2008. The data of the last 12 years were derived from dedicated DGPS surveys performed following the methods proposed by [37]. The differences in the area between the shorelines acquired in different years were calculated in terms of annual gains and losses.

One of the longest and most complete sets of daily discharge data of the Arno River was also analyzed. The daily discharge data were recorded at the S. Giovanni alla Vena gauge (data from 1924 to 2020; https: / / www.sir.toscana.it/consistenza-rete), $35 \mathrm{~km}$ inland from the river mouth (Figure $1 \mathrm{~b}$ ). The discharge value measured at this gauge is significant because it could be considered close to the discharge value at the river mouth, considering that there are no important tributaries downstream from the gauge.

The trend of the daily discharge data since 1924 has been analyzed to identify the main variations of that period.

The return times for flood events were calculated as opposites of probability:

$$
p=\frac{1}{T}
$$

where $p$ is the probability and $T$ the return time. This equation can be applied for frequent events, but it can be difficult to determine the return time of an extreme event if the occurrence of these events is too small in the series history [40]. For this statistical reason, we investigated the role of flow events with a maximum return time of about eight years. 
Table 1. Census of shoreline data used in this study.

\begin{tabular}{|c|c|c|c|c|}
\hline Year & $\begin{array}{c}\text { Ownership } \\
\text { Organization }\end{array}$ & Data Type & Properties & Source \\
\hline 1878 & I.G.M & Cartography & Scale $1: 25,000$ & This work \\
\hline 1907 & I.G.M & Cartography & Scale $1: 25,000$ & This work \\
\hline 1928 & I.G.M & Cartography & Scale $1: 25,000$ & This work \\
\hline 1944 & R.A.F. & Aerial photographs & Black and white film & [22] \\
\hline 1954 & Tuscany Region & Aerial photographs & Black and white film & [22] \\
\hline 1965 & I.G.M & Aerial photographs & Black and white film & [22] \\
\hline 1975 & Tuscany Region & Aerial photographs & Black and white film & [22] \\
\hline 1978 & Tuscany Region & Aerial photographs & Color film & [22] \\
\hline 1982 & Tuscany Region & Aerial photographs & Color film & [22] \\
\hline 1982 & I.G.M & Aerial photographs & Black and white film & [22] \\
\hline 1986 & I.G.M & Aerial photographs & Black and white film & [22] \\
\hline 1990 & I.G.M & Aerial photographs & Infrared & [22] \\
\hline 1996 & Tuscany Region & Aerial photographs & Black and white film & [22] \\
\hline 2003 & Orthophoto & Aerial photographs & Black and white film & [22] \\
\hline 2004 & Pisa Province & Aerial photographs & Color film & [22] \\
\hline 2008 & & DGPS measurements & & [34] \\
\hline 2009 & & DGPS measurements & & [34] \\
\hline 2010 & & DGPS measurements & & {$[34]$} \\
\hline 2011 & & DGPS measurements & & [34] \\
\hline 2012 & & DGPS measurements & & [34] \\
\hline 2013 & & DGPS measurements & & [34] \\
\hline 2014 & & DGPS measurements & & [34] \\
\hline 2015 & & DGPS measurements & & This work \\
\hline 2020 & & DGPS measurements & & This work \\
\hline
\end{tabular}

In order to identify possible correlations, the set of discharge data were analyzed and compared with the erosion trends, as documented by the study of the shoreline positions. Since a rigorous statistical treatment of the data was not possible because of the limited number of shoreline measurements (despite the long period considered), a qualitative comparison was made between the trend of erosion and the trend of discharge.

The trend of the selected flow range was compared with erosion over time by using a moving average calculated over ten years. The use of the moving average to understand the trend of river discharge is a validated method, as demonstrated by several authors (e.g., [41-43]). To support the analyses, we investigated Sentinel-2 images acquired during two recent flood events occurred on 3 February 2019 and on 3 December 2019, in the most frequent wind and sea state (winds and waves from NW and SW, respectively; Figure 1d) in order to identify the presence of sediments and their longshore and offshore dispersion. The selected images were analyzed by means of the tone mapping technique using Photomatix, a program that allows the user to choose among different HDR profiles. After numerous tests, the use of the profile called "Painterly" was chosen. This profile gives the image a very photographic look and a well-exposed dynamic range. The image acquires an aspect that is very similar to the one perceived by the human eye and is often referred to "as the eye sees" in the field of photography. After the application of this profile, the parameters of gamma, luminance and contrast varied, so as to make more readable all the information contained in the images. This method makes it possible to qualitatively identify the area subject to solid transport (according to the different shades and gradations of color). Moreover, the method allows the identification of flow lines of solid transport direction that show the dispersion of sediments out of the mouth towards the coast.

In addition to the study of these two recent events, in order to extend the analyses of the plumes generated by the Arno River, we considered 151 frames from the Landsat (5, 7 and 8) and Sentinel-2 satellites. All the images were filtered at a threshold of less than $20 \%$ cloudiness during the download procedures and were then checked manually. Specifically, 51 Sentinel-2 frames were chosen from 2015 to 2020 and 101 Landsat frames from 1984 to 
2020. In particular, in this second case 68 frames were from Landsat 5,14 from Landsat 7 , and 19 from Landsat 8 . The red band was analyzed for both satellites, corresponding to bands number 4 for Sentinel-2 and Landsat 8 and to number 3 for Landsats 5 and 7 . A good correlation was found between the red band (630-690 nm) reflectance values and low-to-moderate turbidity [44-47]. The images were resampled on the same matrix. Two grids were extracted. The first provides the maximum value recorded in the analyzed images for each pixel, while the second provides the mean value calculated using the analyzed images for each pixel.

In an attempt to understand whether the types of sediment transported by the river were suitable to counter coastal erosion, we performed grain size analyses on sediments sampled on the riverbed near the city of Pisa (where the sediments left by the river were easy to sample) and on the beach (area C, Figure 1) immediately after a flooding event that occurred on 3 December 2019, which was one of most representative in this area, in terms of both wave direction and fluvial discharge. The samples were dried in an oven at $40{ }^{\circ} \mathrm{C}$ for $48 \mathrm{~h}$. Each sample was then weighed and analyzed by means of standard sieving with mesh size $1 \mathrm{~mm}, 0.5 \mathrm{~mm}, 0.315 \mathrm{~mm}, 0.250 \mathrm{~mm}, 0.125 \mathrm{~mm}$ and $0.063 \mathrm{~mm}$. After weighing the fraction left in each sieve a grain size curve was constructed using GRADISTAT [48]. Finally, to check the effective ability of solid load to counter coastal erosion, we undertook a dedicated DGPS survey in a small stretch of coast in the southern sector (part of area C) about one month after the flood event of 3 February 2019.

\section{Results}

\subsection{Shoreline GIS Analysis}

The analysis of shoreline positions (Figure 2a-d) shows that more than $2.5 \mathrm{~km}^{2}$ of the studied area experienced constant erosion, while only $0.5 \mathrm{~km}^{2}$ experienced constant advances (Figure 3). The areas most affected by erosion are located in the hydrographic right (Area A, Figure $2 \mathrm{c}$ and the area northward of the Morto Nuovo River, Figure 2a). In the hydrographic left (where erosion has been countered by several engineering interventions such as groins and breakwaters $[22,27,28,49])$ the total area eroded is less in extent compared with Area A, but the erosion is persistent in the area marked B in Figure 2c. Coastal progradation has been documented mainly in the $C$ area of the southern sector (Figure $2 \mathrm{~d}$ ), while minor local advances have also been identified in the northern sector immediately south of the mouth of the Morto Nuovo River (Figure 2b). From a chronological point of view, the highest values of erosion are documented around the years 1954, 1978 and 2012 (Figure 4), while the lowest values of erosion are reported for the periods 1881-1944, 1965-1975, and 2013-2020. It is worth noting that the erosion rates for the period before 1944 are similar to those recorded in the last 10 years (Figure 4 ). 


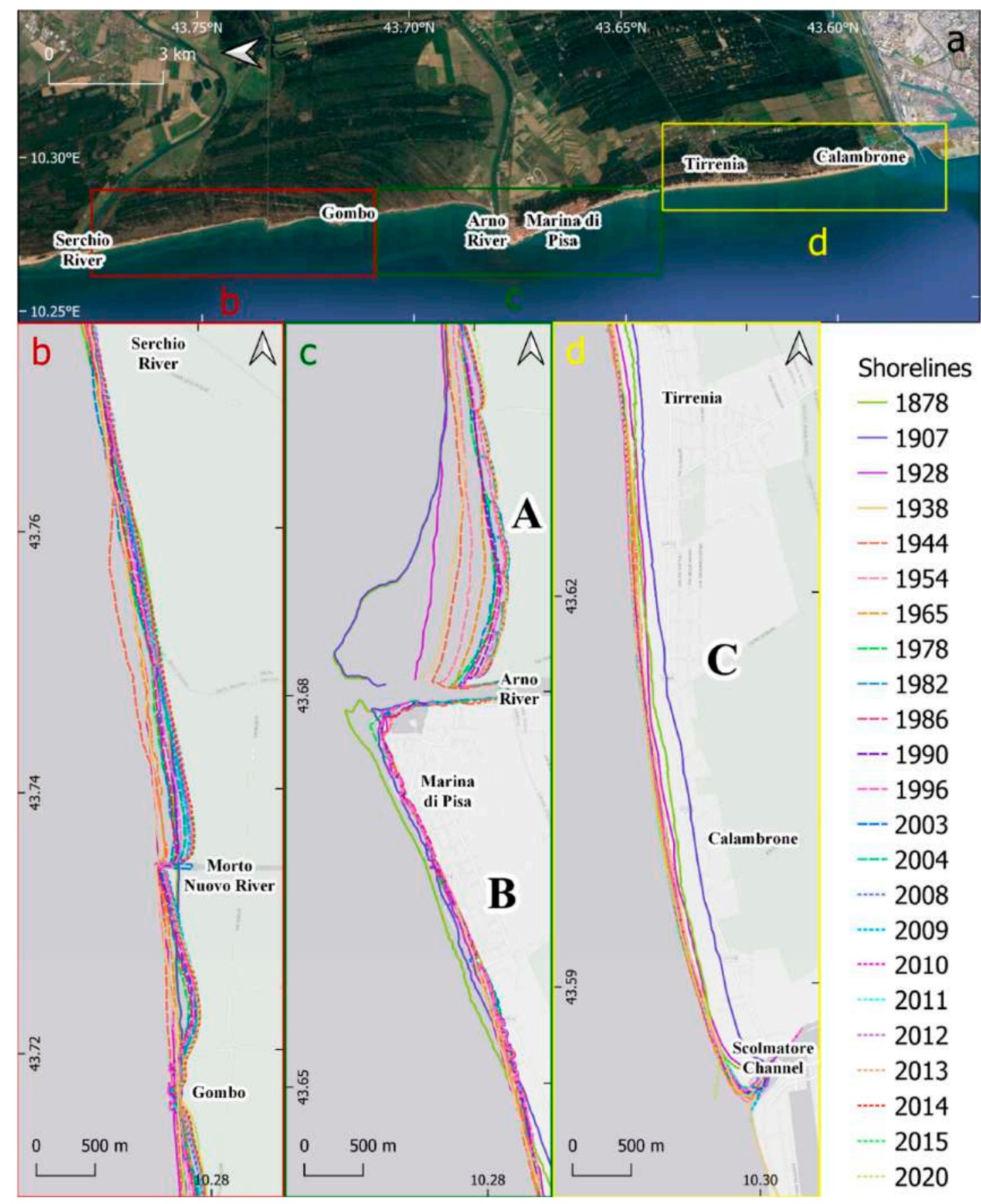

Figure 2. A, B and C indicate specific coastal stretches to which reference has been made in the text. Location of the analyzed coastal sectors $(\mathbf{a}-\mathbf{d})$. Shorelines extracted from the various sources reported in Table 1. Continuous lines: data from historical maps or aerial photography; dashed lines: data from Differential Global Position System (DGPS) measurements. 


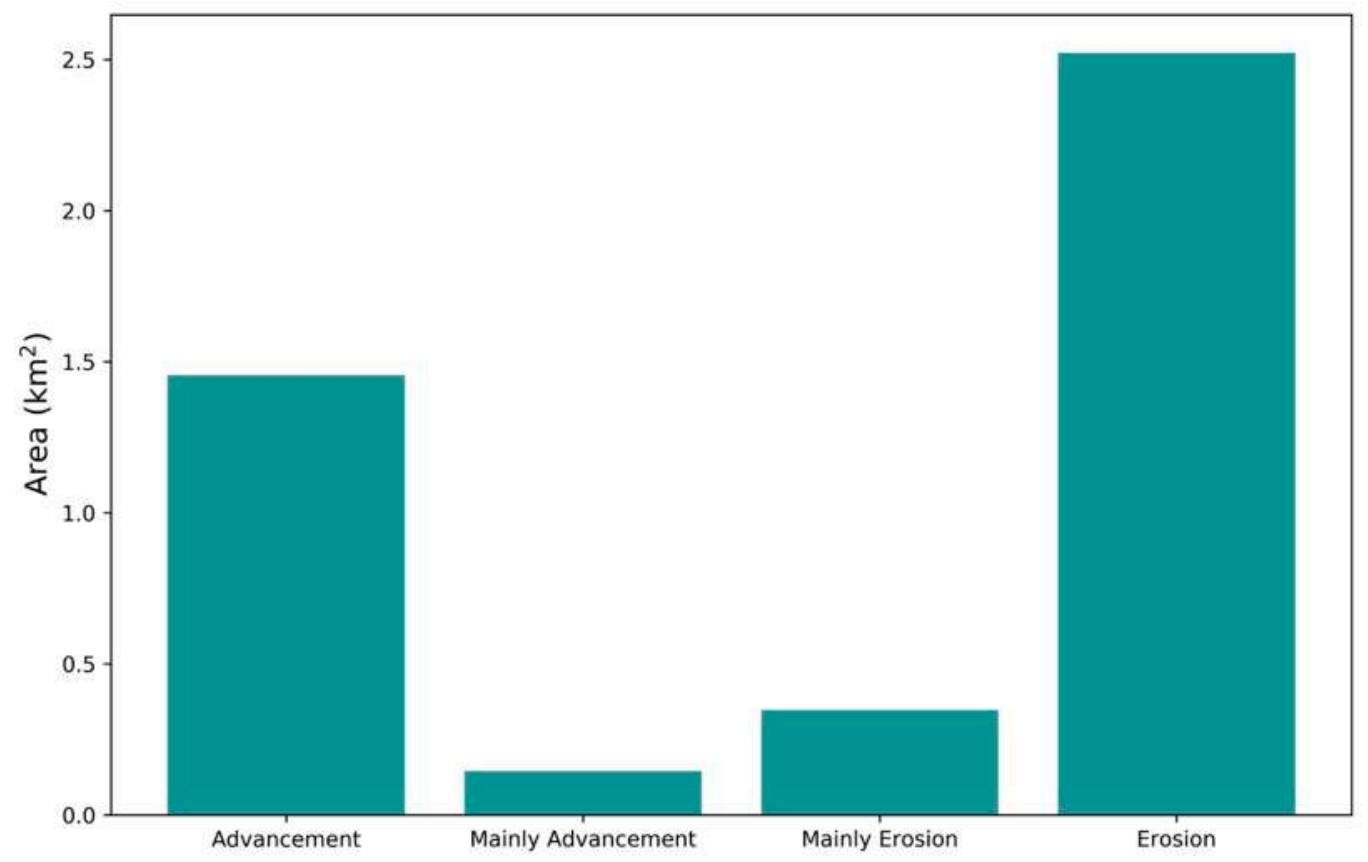

Figure 3. Spatial variation of the investigated coastal area. Analysis of the shorelines in the last 142 years allows identification of the sectors in constant advancement (progradation) and those in constant erosion, those mainly in advancement and those mainly in erosion. In the histogram, the amount of territory that always experienced advancement, always erosion, mainly advancement and mainly erosion was quantified according to the analyses of spatial variation of the shorelines (Figure 2).

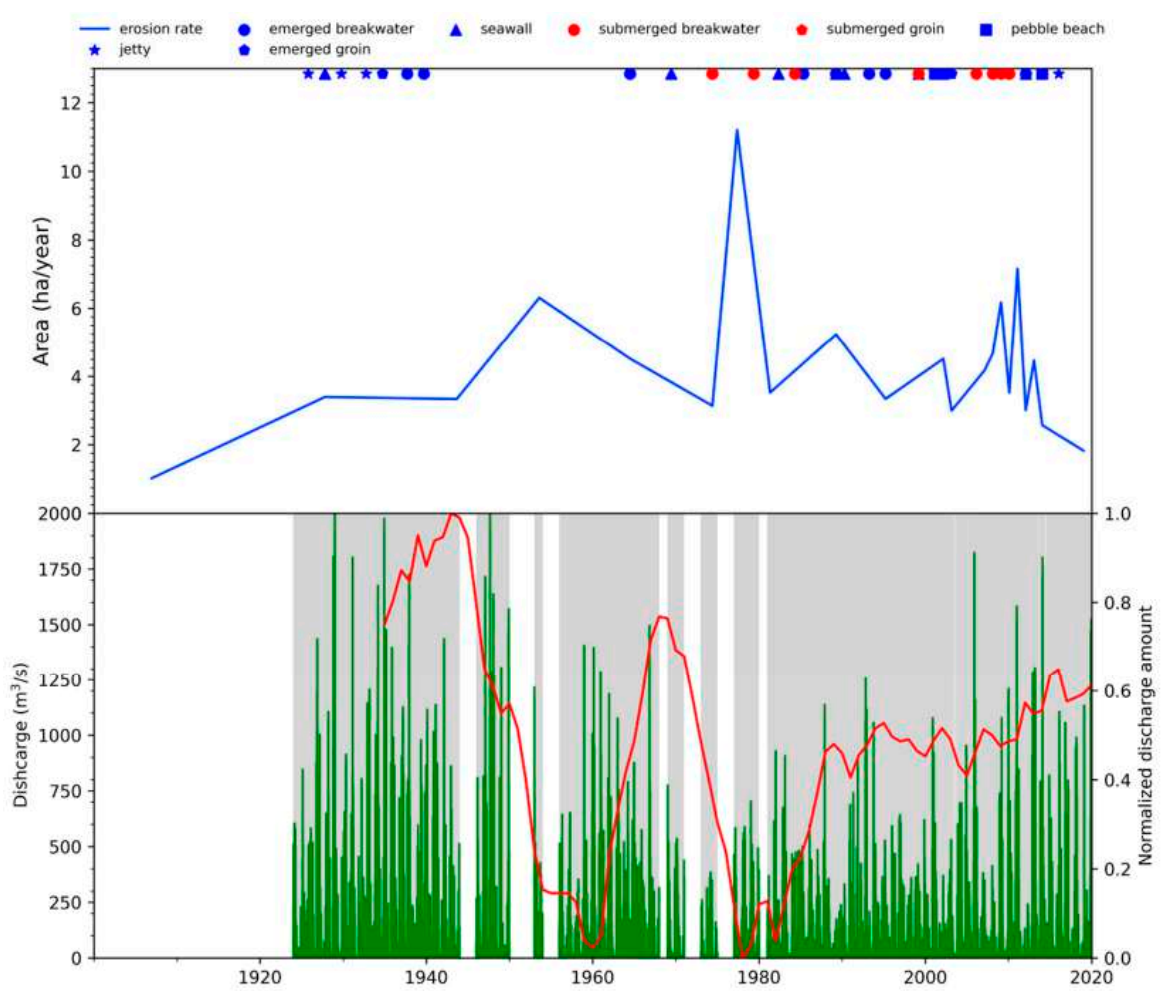

Figure 4. Trend of erosion from 1881 to 2020 of the investigated area (blue line). Top: engineering structures built in the area over time. Daily discharge time series of the S. Giovanni alla Vena gauge data from https:/ / www.sir.toscana.it/consistenzarete (green bars). The white bars indicate an absence of data. The red line shows the amount of normalized discharge using a moving window of 10 years. 


\subsection{Discharge Data Analysis}

Discharge analysis (Figure 4) shows the highest values until 1944, followed by a reduction in the period at the end of the 1950s and around the year 1980. These two periods are separated by a peak in the values of discharge. An increase in discharge values, which are still well below the values recorded before 1944, is documented from the end of the 1980s to the year 2005. Despite some fluctuations, a further increase in the trend is documented after this year. We are aware that the lack of data in the 1950s and 1970s may have affected the results, even if a clear decreasing trend, probably not so marked, can be identified from the available data. Return time analysis of the historical series of $S$. Giovanni alla Vena (Figure 5) with a $100 \mathrm{~m}^{3} / \mathrm{s}$ discretization shows an exponential trend with a one-year return time corresponding to a flow rate of $700 / 800 \mathrm{~m}^{3} / \mathrm{s}$.

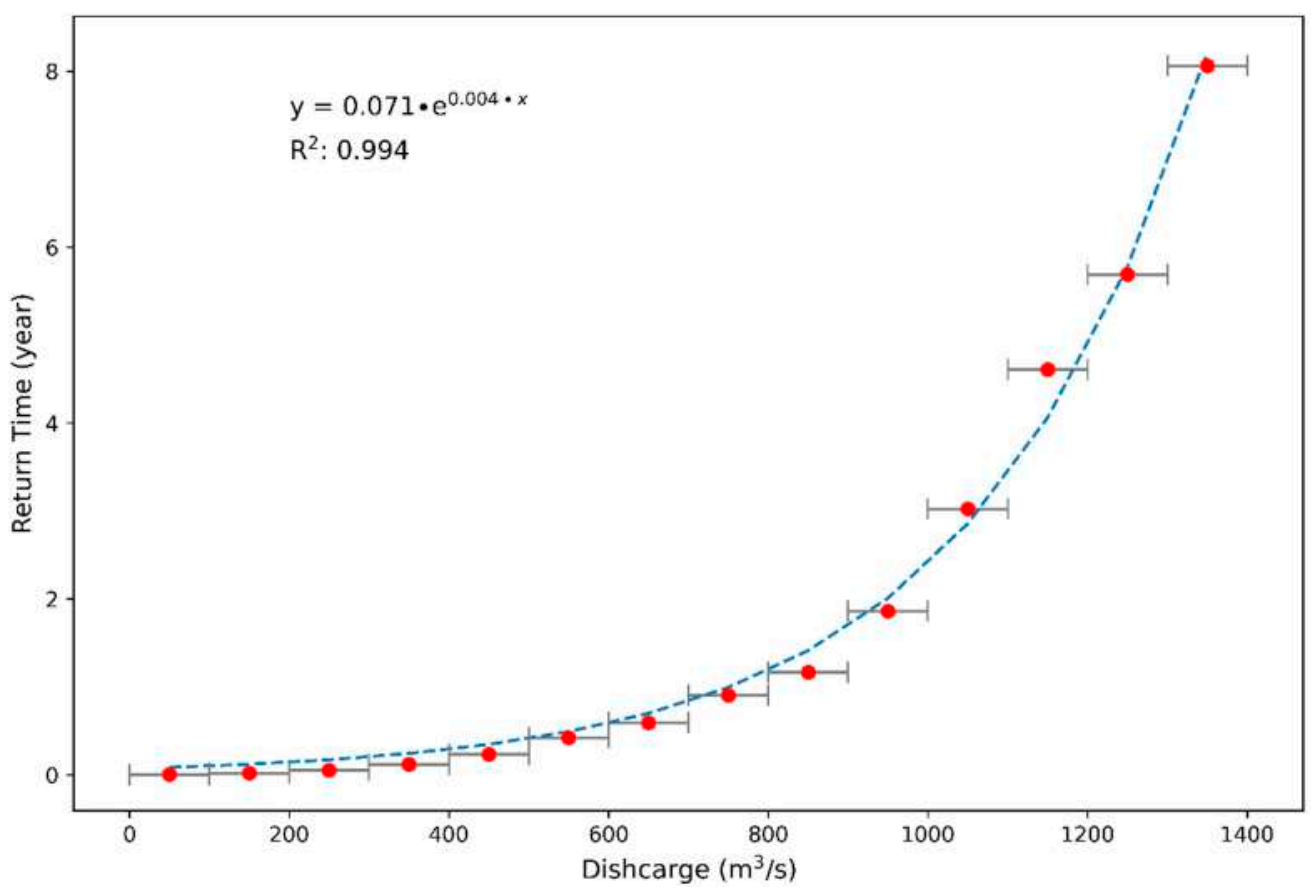

Figure 5. Return times for discharge intervals of the S. Giovanni alla Vena time series. Discretization of the discharge range in $100 \mathrm{~m}^{3} / \mathrm{s}$. The return times show an exponential trend.

\subsection{Remote Sensing Analysis}

The sentinel-2 image recorded at 10:24 a.m. on 3 December 2019 shows the Arno River sediment dispersion along the coast during a flood event characterized by a peak discharge of $902.81 \mathrm{~m}^{3} / \mathrm{s}$ at the $\mathrm{S}$. Giovanni alla Vena gauge (return time of 1.5 years, Figure 5). This event occurred with a much more frequent wave direction varying from $240^{\circ} \mathrm{N}$ to $180^{\circ} \mathrm{N}$ (Tuscany Region, wave buoy of Gorgona: https:/ /www.cfr.toscana.it/index.php?IDS=42 \&IDSS=282). The image processed by tone mapping (Figure 6) shows a wide plume formed by sediments transported by the river during this event and dispersed at the river mouth. Plume n. 1 in Figure 6 covers a total area of about $100 \mathrm{~km}^{2}$. A minor plume (identified as $1 \mathrm{~A}$ in Figure 6) covering a total area of about $10 \mathrm{~km}^{2}$ is also well visible in the image. The dispersion of sediments shows that a large amount of transported sediment was dispersed offshore. In agreement with the wind and wave directions, the plume shows a deviation towards NNW, together with the other minor plumes of the Scolmatore channel located further south. The reconstruction of the flow line allows the identification of two shadow areas in sediment dispersion: one located in the northern sector between the Lame della Gelosia and il Gombo (area A in Figure 6), and the other one situated in the southern sector in front of the village of Marina di Pisa (area B in Figure 6). 


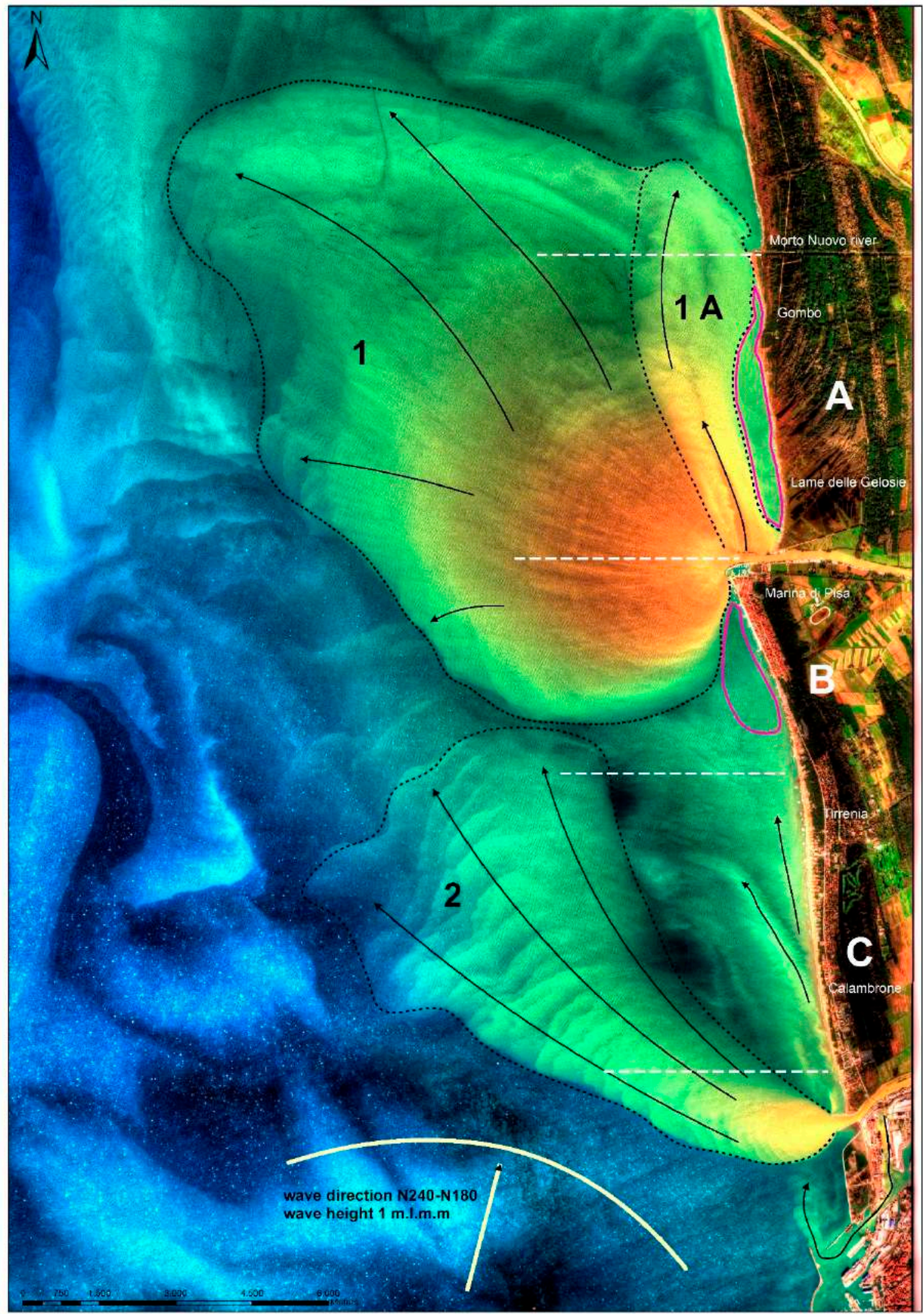

Figure 6. Sentinel-2 image showing the Arno flood event of 3 December 2019 characterized by a fluvial discharge of $902 \mathrm{~m}^{3} / \mathrm{s}$ at the S. Giovanni alla Vena gauge and wave direction N 240-180. A, B and C indicate specific coastal stretches to which reference has been made in the text. Black arrows show the sediment flow directions derived from a qualitative analysis of the image using the tone mapping method to emphasize the contrast. Dashed lines highlight the main plumes at the different river mouths. Purple lines enclose the shadow areas. 
The Sentinel-2 image recorded at 10:22 a.m. on 6 February 2019 shows the final phase of the flood event of 3 February, characterized by a wave direction from $300^{\circ} \mathrm{N}$ (which is the second in occurrence), and a fluvial discharge of $1131 \mathrm{~m}^{3} / \mathrm{s}$ at the S. Giovanni alla Vena gauge (return time of 3 years, Figure 7). In this case a significant volume of sediments was dispersed offshore, while the entire solid longshore transport faced south (Figure 6). Apart from the first kilometer to the north of the river mouth, the northern sector does not receive any sediments. In the southern sector, the shadow area in front of Marina di Pisa is still visible; instead, according to wave direction analyses, a part of the solid load reaches the southernmost area in correspondence to the village of Tirrenia and the borough of Calambrone (area C, Figure 1d).

A more generalized analysis of sediment dispersion of the Arno River along the coast was performed considering several (Landsat and Sentinel-2) images for the period 1984-2020. Specifically, Figure 8 shows the result of processing the 50 Sentinel-2 and the 101 Landsat 5, 7 and eight images. The analysis was performed using the red band. In the first processing data the final images (Figure $8 \mathrm{a}, \mathrm{c}$ ) were obtained considering in each pixel the mean value recorded in all the analyzed images. Specifically, the mean value on the red band of the 50 analyzed Sentinel-2 images is recorded in each pixel of Figure 8a, while the mean value of the 101 analyzed Landsat images is recorded in each pixel of Figure 8c. In the second processing data the final images are obtained considering in each pixel the maximum value recorded on the red band in all the analyzed images (Figure $8 \mathrm{~b}$ for the Sentinel-2 Images and 8d for the Landsat images.). All the images obtained show that the area to the north of the river mouth is characterized by a greater reflection on the red band than the southern area. This suggests a different distribution of the sediment between the northern part and the southern part. In particular, the southern area near the mouth of the river has the lowest reflection values for the entire stretch of coast studied. Moreover, the shadow areas described in the events previously described (Figures 6 and 7) in the northern and southern sectors are confirmed also in Figure $8 b, d$, which consider the maximum pixel value. The images based on the mean values (Figure 8 a,c) allow identification of the main distribution of the sediment in the period studied (considering only the mean value of the differences among the various sectors are minimized). The images based on the maximum values (Figure $8 b, d$ ) accentuate the differences between the areas that received a greater supply of sediment and those with the opposite behavior.

\subsection{Post-Flood Field Investigations}

In C area between the village of Tirrenia and the borough of Calambrone, new DGPS shoreline measurements acquired before and about one month after the flood of 3 February 2019 document an advance of the coastline (Figure 9). More precisely, on a linear stretch of coast of about $6.5 \mathrm{~km}$, there was an increase of the territory of about $16,400 \mathrm{~m}^{2}$ following this event, which occurred under more favorable conditions of the wind and sea states (wind and wave directions from NW) for nourishment of the southern sector. Grain size distribution of sediment acquired in two points (the first on the sediments left by the river on the city center embankment and the second on the beach of the area C: Figure 1b) shows an evident analogy between the samples and a predominance of coarse sand (50\% ca) and medium sand ( $45 \% \mathrm{ca}$ ) in both cases (Figure 10), excluding the plumes identified by remote sensing that were formed by fine material unsuitable for beach nourishment. 


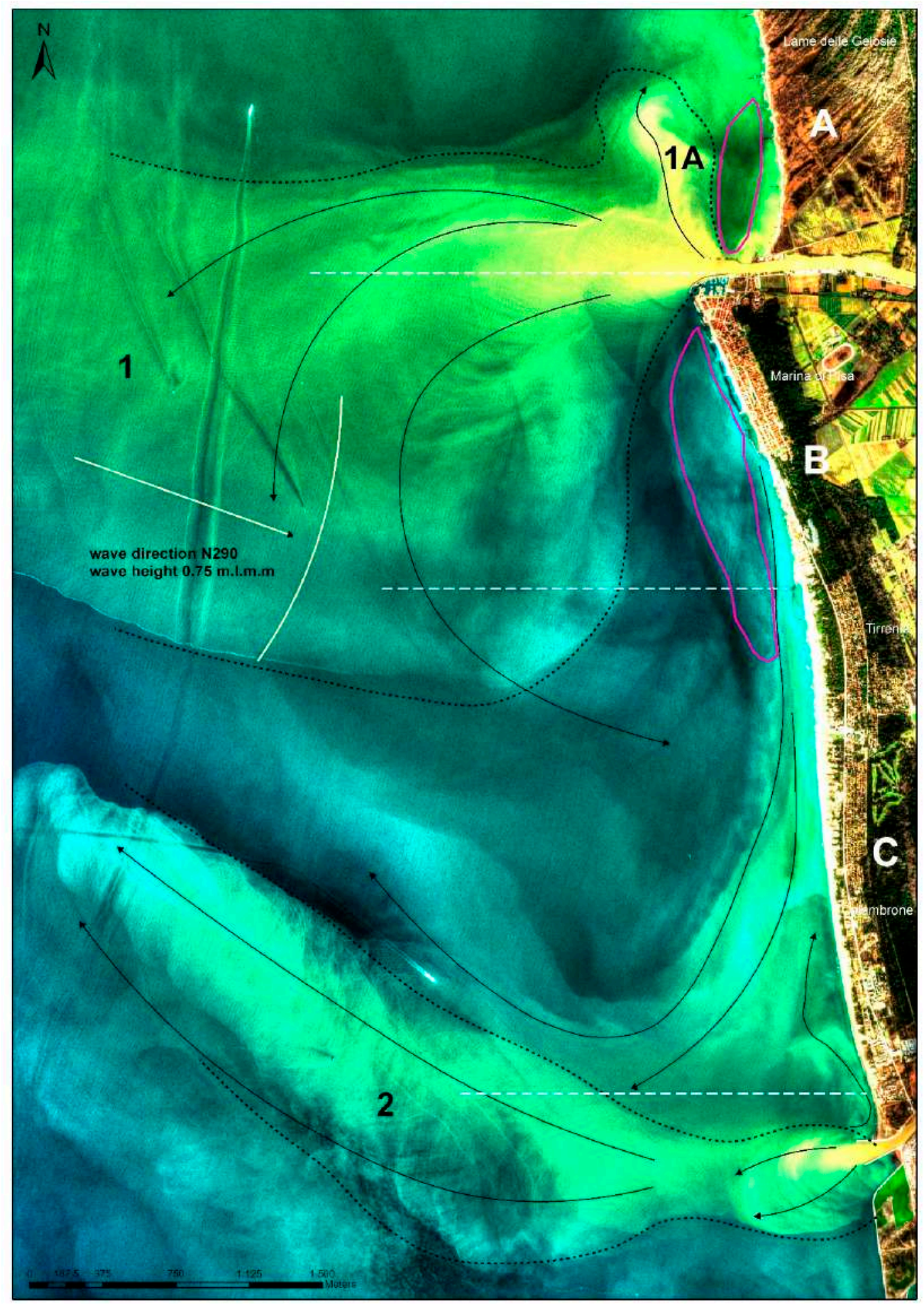

Figure 7. Sentinel-2 image of 6 February 2019 showing the end of the Arno flood event of 3 February 2019 characterized by a fluvial discharge of $1131 \mathrm{~m}^{3} / \mathrm{s}$ at the S. Giovanni alla Vena gauge and wave direction N 290. A, B and C indicate specific coastal stretches to which reference has been made in the text. Black arrows show the sediment flow directions reconstructed after qualitative analysis of the image using the tone mapping method to emphasize the contrast. Dashed lines highlight the main plumes at the different river mouths. Purple lines enclose the shadow areas. 


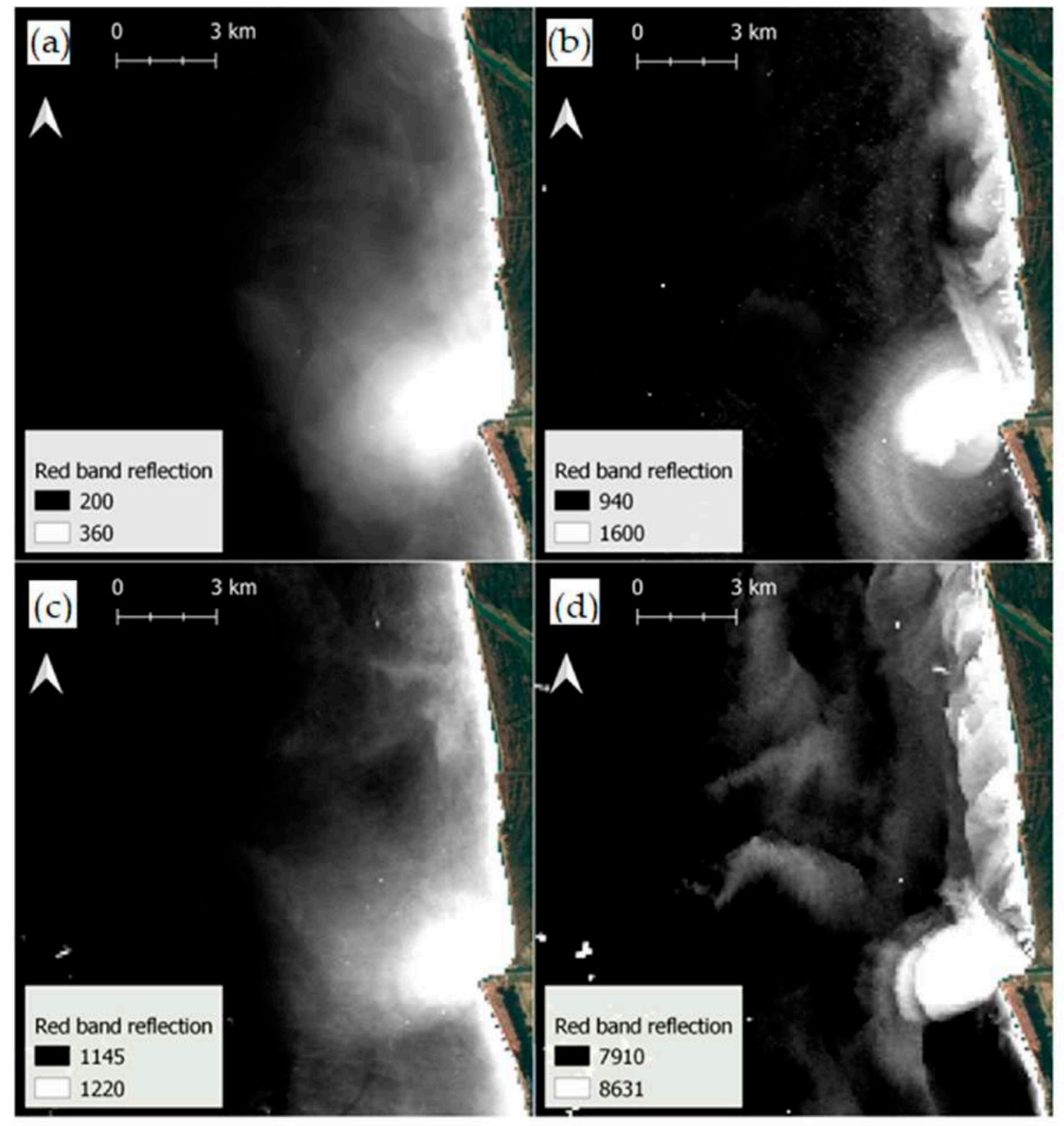

Figure 8. Analyses of the red band of 50 Sentinel-2 images and 101 Landsat images, acquired during the period 1984-2020. In each pixel the mean value recorded in the Sentinel-2 images (a) and Landsat images (c) respectively, are shown. In each pixel the maximum value recorded in the Sentinel-2 images (b) and Landsat Images (d), respectively, are shown. 


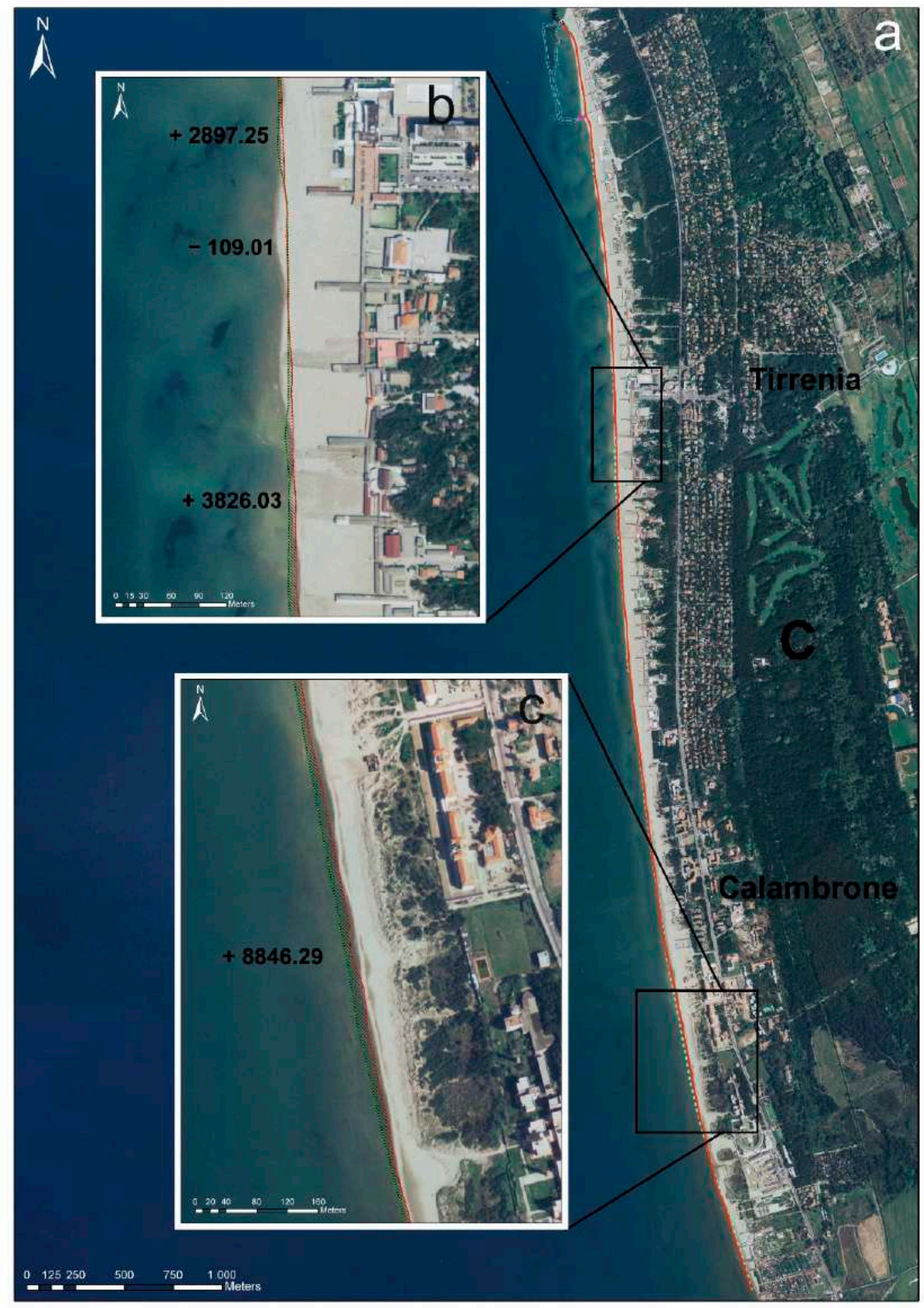

Figure 9. (a) Coastline monitoring in the area C, 23 days after the event of 3 February 2019. Red line DGPS measurements acquired on 1 October 2018, and yellow line DGPS measurements acquired on 26 February 2019. The numbers in (b,c) represent the areal changes (in $\mathrm{m}^{2}$ ) between the two acquisitions. 
(a)

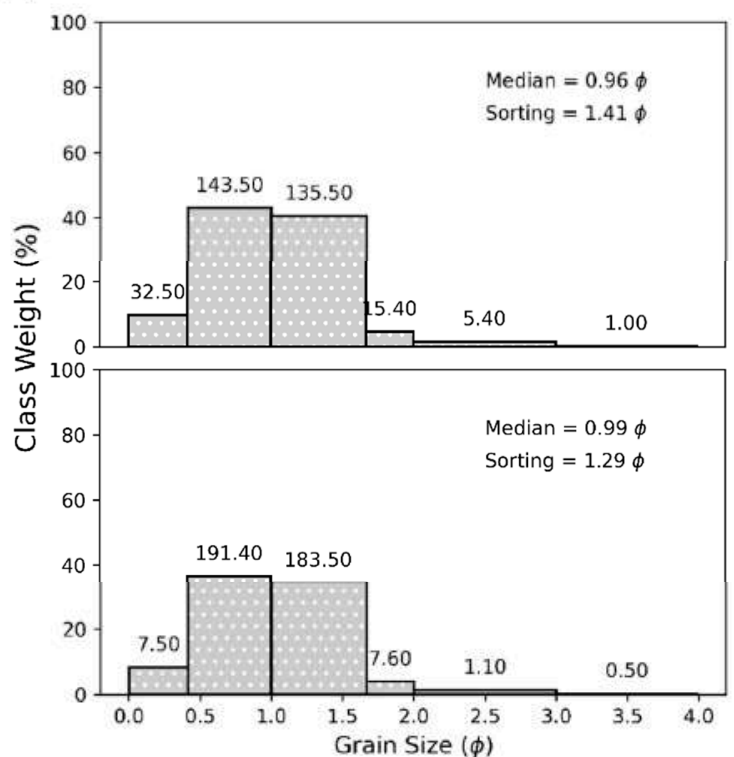

(b)

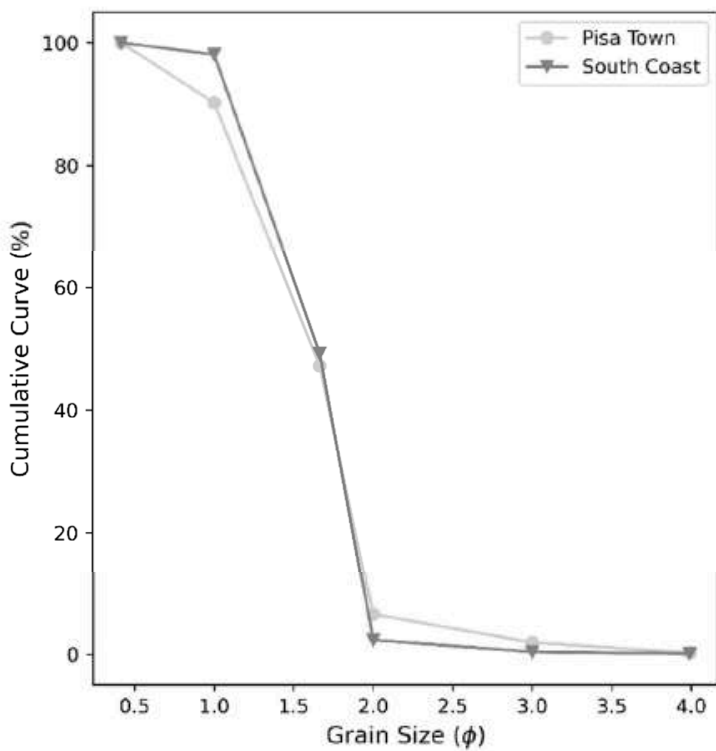

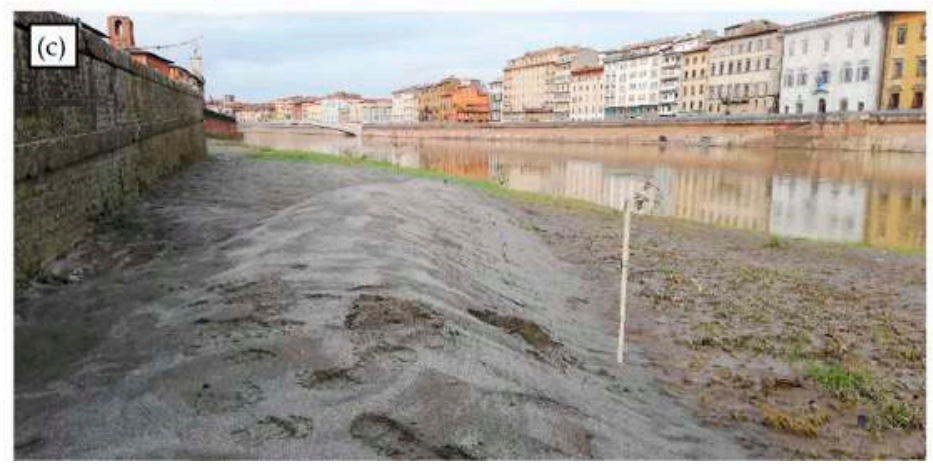

Figure 10. Grain size analysis of sediment samples in the city of Pisa and along the South Coast. (a) Histogram of grain size $(\phi)$ of samples in Pisa (top) and along the South Coast (bottom); (b) cumulative curve of two samples; (c) photograph showing sampling site.

\section{Discussions}

The analysis of the coastline position during the last 142 years represents the most comprehensive study ever performed on the history of coastline evolution of the Pisa coastal plain. Our results actually expand the work of [8], both in terms of time ([8] considers only the period between 1944 and 2015) and resolution, since they mainly consider satellite images. Analysis of the data shows a predominance of areas permanently affected by erosion, corresponding to $60 \%$ of the total area investigated. Following a period of progradation due to the phases of Arno delta construction beginning at about $3000 \mathrm{ka}$ BP [29-32,50], different parts of the Pisa plain experienced marked coastal erosion, which started at the end of the 19th century and increased after the construction of the river mouth jetty, especially on the hydrographic right $[20,22,28,34]$.

However, with the exception of area A (Figure 1), which was particularly affected by erosion, the overall value of erosion remained low until the 1950s when there was a rapid documented increase of the process. Erosion was particularly severe at the end of the 1980s, probably caused, among other things, by the effects of dredging/damming [51,52]. The following period was characterized by an increase in erosion around 2010, while a reduction in the erosion rate has been documented in the last eight years (since 2012). The period most affected by erosion was around the 1980s, while the areas that most experienced this phenomenon are the area northwards of the Morto Nuovo River, area A 
where the Arno mouth jetty limits sediment flow that evolved naturally until 2001, and area $B$ area, where several human interventions designed to mitigate the erosion effects have been constructed since the beginning of the twentieth century $[28,36]$.

In the absence of precise modern measures of solid load, [53,54] provide an estimate of $1.5 \mathrm{t} / \mathrm{yrs}$. In addition, only eight sporadic measurements were made far from the river mouth by [55]. It is possible to indirectly define the role of solid load in countering erosion, in an attempt to create a correlation with fluvial discharge $[8,14]$. The sporadic data obtained by [55] made it possible to highlight the presence of sand in the suspended sediments transported by the river, starting from the discharge value of about $500 \mathrm{~m}^{3} / \mathrm{s}$ at the Nave di Rosano gauge (Figure 1). Figure 11a shows the sections of S. Giovanni alla Vena and of Nave di Rosano, while Figure 11b shows the relationship between the discharges of these two stations. The linear regression of the two datasets is represented by the following equation:

$$
y=0.60 x-1.86,
$$

where $y$ is the discharge of Nave di Rosano and $x$ the discharge of the S. Giovanni alla Vena. The equation highlights that the discharge at Nave di Rosano is about $60 \%$ the discharge at S. Giovanni alla Vena. $R^{2}$ of the linear regression is 0.79 and RMSE (Root Mean Square Error) is $40.25 \mathrm{~m}^{3} / \mathrm{s}$. By using the outflow scale provided by the Regional Hydrologic Service of the two investigated stations, we can derive velocity as a function of discharge (Figure 11c). A discharge of $500 \mathrm{~m}^{3} / \mathrm{s}$ at Nave di Rosano corresponds to a flow rate of ca $1 \mathrm{~m} / \mathrm{s}$. The same flow rate at $\mathrm{S}$. Giovanni alla Vena corresponds to a little less than $700 \mathrm{~m}^{3} / \mathrm{s}$ discharge.

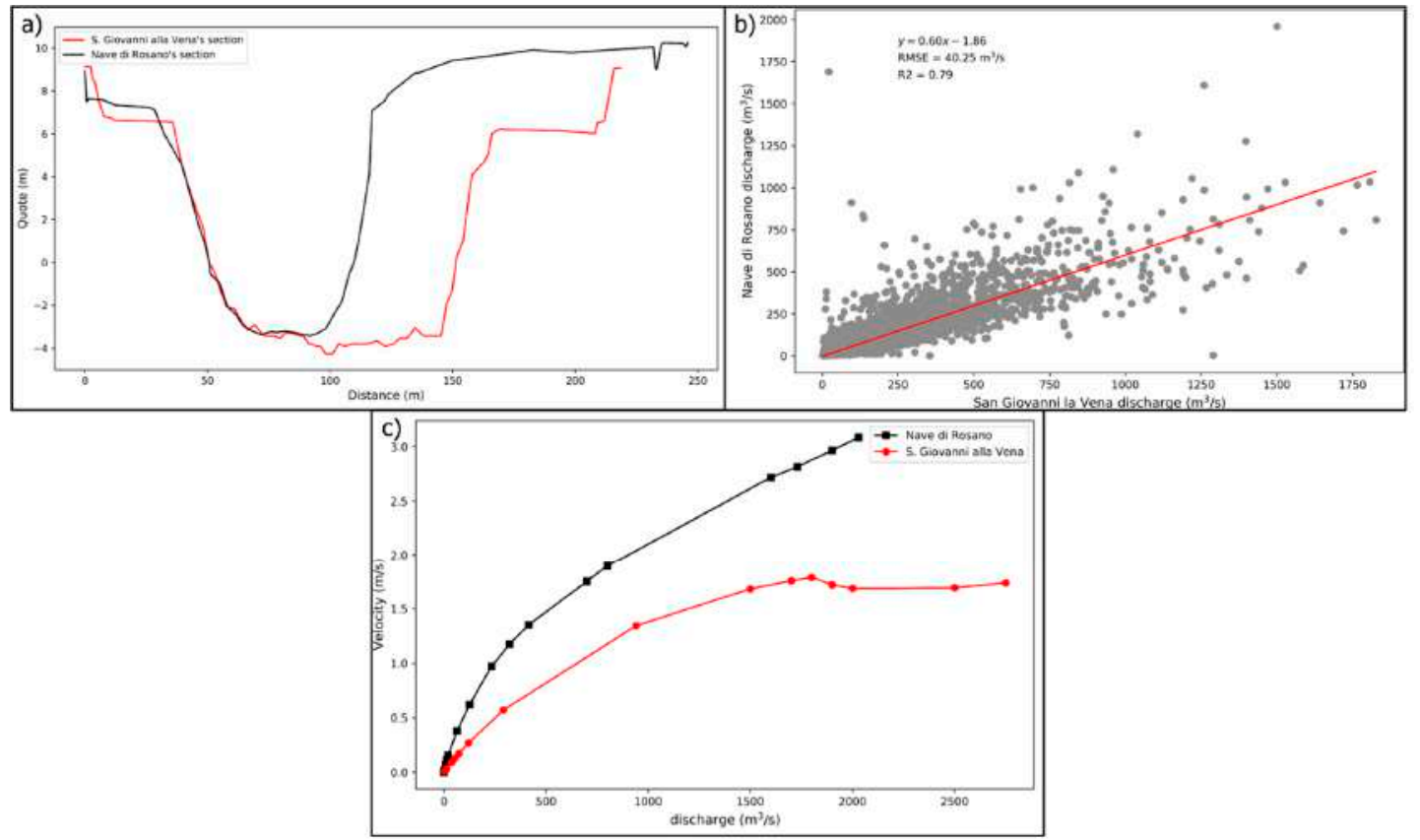

Figure 11. (a) River cross-section at S. Giovanni alla Vena gauge (red line) and Nave di Rosano (black line); (b) relation between discharges of the Arno River at S. Giovanni alla Vena and at Nave di Rosano; (c) relation between discharge and flow velocity resulting from the outflow scale at S. Giovanni alla Vena (red curve) and at Nave di Rosano (black line). The location of the two gauges is highlighted in Figure 1c.

For this reason, it may be hypothesized that values of discharge starting from $700 \mathrm{~m}^{3} / \mathrm{s}$ at $S$. Giovanni alla Vena are the most suitable to counter coastal erosion transported by suspended sand. These data are consistent with those observed in the Tiber River [56] in a climatic and environmental setting not very different from the Arno River catchment.

The role of solid load in countering the coastal erosion of this territory is documented by the qualitative anticorrelation between fluvial discharge and erosion rate (Figure 12). In particular, Figure 12 shows a minimum of fluvial discharge during the years 1954, 1978, 
2012 corresponding to a peak of erosion, while in the years 1928-1944, 1954-1975, and after 2012 the erosion rate (despite some fluctuations) diminished, and the fluvial discharge increased. In the period 1960-2012 the river discharge was significantly low. This was particularly true for events $>700 \mathrm{~m}^{3} / \mathrm{s}$ (purple bars in Figure 12). It is logical to presume that the same occurred with the transported sediment load. It is perhaps for this reason that several authors (e.g., [11,22,57]), on the basis of the data available until 2010, considered the Pisa coastal plain to have evolved as a relict beach. However, this general trend seems to have changed over the last decade, with a slight decrease in erosion possibly caused by a slight increase of the solid load related to an increase in events greater than $700 \mathrm{~m}^{3} / \mathrm{s}$. In more recent years the data concerning the solid transport of sand in suspension starting from $700 \mathrm{~m}^{3} / \mathrm{s}$ have been more reliable, and large environmental changes (in sections of the riverbed, availability of sediments resulting from different soil use in the catchment basin, etc.) can be excluded. Moreover, the quality of the shoreline data in the last 12 years (through high frequency DGPS acquisition) has made it possible to better understand the relationship between river discharge and the trend of erosion.

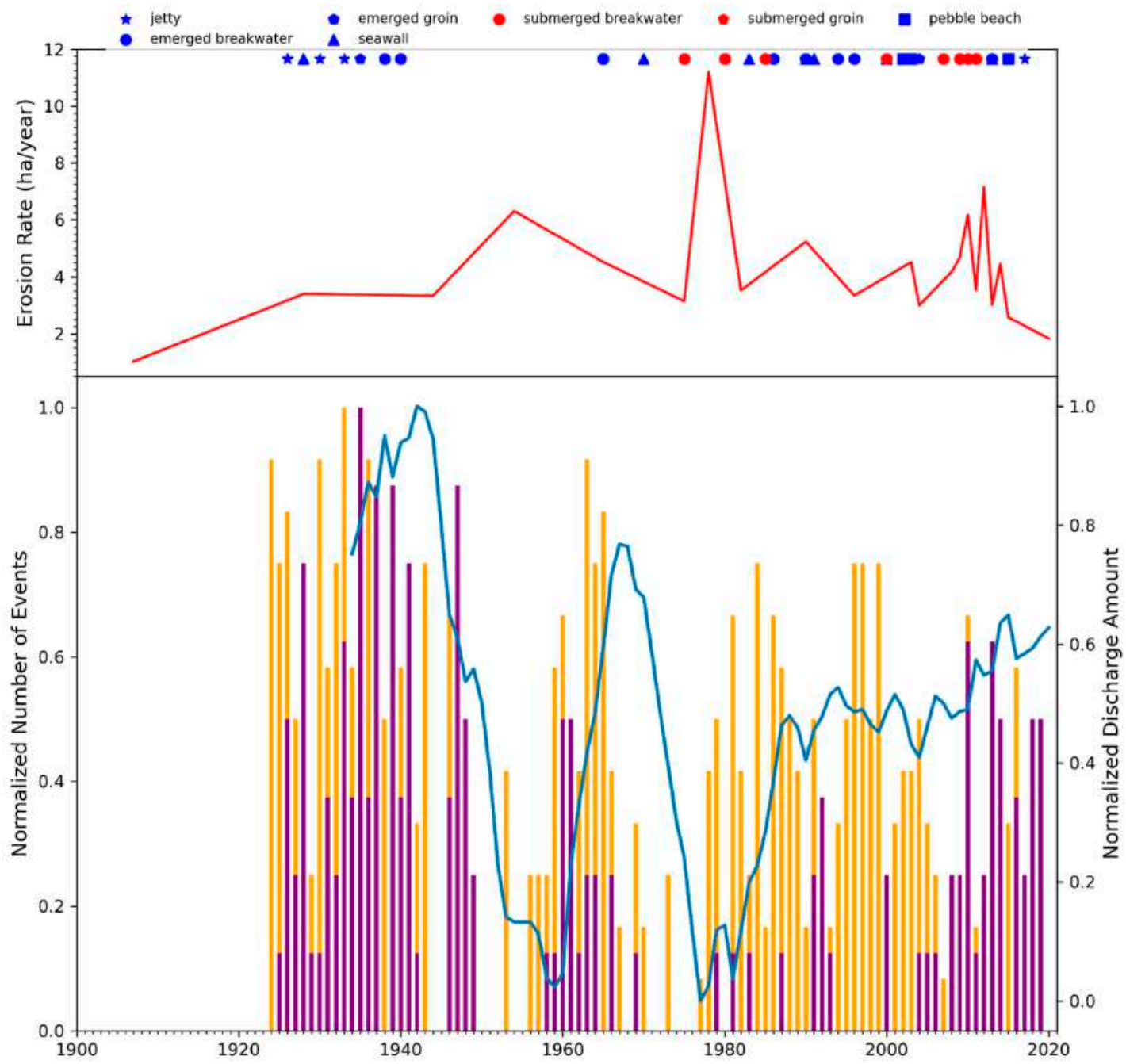

Figure 12. Relation between erosion rate of the coast (red line) and discharge of the Arno River over time. Number of flood events lower than $700 \mathrm{~m}^{3} / \mathrm{s}$ recorded per year (yellow bars) and the number of flood events higher than $700 \mathrm{~m}^{3} / \mathrm{s} \mathrm{recorded}$ per year (purple bars). Data on number of events from Table S1. Normalized discharge amount with a 10 year mobile window of whole time series (blue line).

The study of Sentinel-2 images related to the flood event of 3 December 2019 with fluvial discharge of ca $900 \mathrm{~m}^{3} / \mathrm{s}$ (a little higher than the threshold of $700 \mathrm{~m}^{3} / \mathrm{s}$ identified 
for the transport of sand), allowed us to identify the presence of a large plume of sediments in front of the mouth of the Arno River. Moreover, grain size analysis of the transported sediments highlighted the presence of well-sorted medium sand $(>0.315 \mathrm{~mm})$, perfectly consistent with the sediments characterizing different parts of the Pisa coastal plain [37] and suitable for coast nourishment. However, the sediments forming the plume were largely dispersed offshore.

Analysis of the images presented in Figures 6-8 also made it possible to infer that strong erosion still characterizing some sectors of the Pisa coastal plain is related to the mode of longshore dispersion of the sediments that reached the coastline. Indeed, the analyzed flood event can be considered representative of most of the floods characterizing the Pisa coastal plain, which took place under the most common wind and sea state (more than $90 \%$ of events occurred with wind and wave directions from W/SW). The reconstruction of the flow lines (Figure 6) shows that areas A and B were not enhanced by the dispersion of sediments transported during the floods that occurred under these wind and sea state conditions.

The study of the events of 3 February (higher in discharge: ca $1100 \mathrm{~m}^{3} / \mathrm{s}$ ), which arose in less frequency but had more suitable sea state conditions in the southern sector (wind and wave directions from NW) underlines the presence of the same shadow areas. The most favorable condition for nourishing the northern beaches is the occurrence of floods with winds blowing and waves coming from SW, while the most favorable condition for nourishing the southern sector is the occurrence of floods with waves from the $\mathrm{W}$ and/or NW (Figure 6). Thanks to these studies it is possible to hypothesize that coastal sectors that are not fed by sediments during these events generally lack sedimentary supply. These interpretations have been also confirmed by analyses on several Landsat and Sentinel-2 images showing the process of sediment dispersion over the chronological interval 19842020. In all the cases analyzed, many Arno River sediments do not reach the coastline but are dispersed offshore. This aspect is likely to have more relevant effects on coastal erosion than the decrease in the solid load of sediments transported by the Arno River, as hypothesized by several authors $[11,22,30]$. However, our work also suggests that sediment load may have had an opposite trend in the last decade, as shown by the analysis of fluvial discharge analysis, with a slight increase in the number of events higher than $700 \mathrm{~m}^{3} / \mathrm{s}$, suitable for sand transport.

As highlighted by Sentinel-2 analyses, the shape of the jetty at the river mouth also played a key role in the dispersion of sediments offshore and in the creation of shadow areas longshore. As documented in Figures 6 and 7, some sediments reach the northern sector passing through an opening in the jetty (see plume 1a, Figure 6), but this intervention is still insufficient to limit the formation of the shadow zone in the northern sector. In this respect, it may be useful to seriously consider the maintenance/change of shape of this engineering structure, built at the beginning of the 1900s, which was supposed to avoid the silting up of the river mouth and to reduce the flood hazard that is creating significant coastal erosion problems. In more recent years, a similar crucial role has been played by the jetty at the Morto Nuovo River. It is important to reflect on the extensive use of expensive and impacting engineering defenses in this area, which do not always give the expected protection results. In some cases the defenses have been destroyed by coastal erosion as documented by [28], and in other cases the defenses have shifted the coastal erosion from one coastal sector to another (e.g., areas of the village of Marina di Pisa, where erosion and coastal defenses are moving southwards and seaward acting on the submerged profile) $[28,34]$.

The possibility for the solid load to reach the coastline to counter erosion was confirmed by using a DGPS to measure a small stretch of coast in the southern sector in front of the village of Tirrenia (area C, which exhibits a general trend of stability, reached by sediments during the described events). We documented an advance by comparing the shoreline position obtained by DGPS before the event of 3 February 2019 with the shoreline measured about one month after this event. Since grain size analysis of the sediments of 
the riverbed and of the southern coastal area are consistent and correspond to medium sand, we can deduce that part of the southern coast receives sediments from the Arno River. Furthermore, the grain size range of the transported sediments is useful to counter erosion. On the contrary, areas A and B are affected by erosion because they are not influenced by the dispersion of the sediments of the plume under different marine weather conditions.

\section{Conclusions}

Coastal erosion in the Pisa coastal plain at the end of the nineteenth century increased according to our review, in particular after the 1950s, at the end of the 1970s and around 2012. After 2012 there is a slight decrease in the erosion rate, which reaches the same values observed at the beginning of the nineteenth century. On the basis of the erosion rate and the remote sensing analyses on sediment dispersion, we can state that the particular shape of the jetty and of other engineering defenses at the mouth of the Arno River favors the dispersion offshore of the sediments carried by the watercourse and determines the formation of shaded areas in longshore sediment distribution. Despite the construction of several engineering defenses, particularly active erosional trends still appear in two coastal areas (in front of the small town of Marina di Pisa in the southern sector and between the locations of Lame della Gelosia and il Gombo in the northern sector). Erosion is particularly evident in the first location, while it has been countered by numerous, repeated, impacting and expensive engineering interventions for coastal protection in the second. The fluvial discharge data of the Arno River highlight a discharge decrease that roughly matches the periods that correspond to an increase in erosion. On the other hand, the increase in the flow rate recorded in the last decade can be considered a key element for a reduction in the overall erosion rate recorded in this last period. This correlation is particularly true if we take into account flood events with a value of discharge greater than $700 \mathrm{~m}^{3} / \mathrm{s}$, which are those able to transport suspended sand.

The amount of sediment transported by the watercourse has increased in recent years and could certainly counter erosion more effectively if it were possible to reduce the amount of sediment dispersed offshore. Furthermore, it would be important that the sediments were distributed more uniformly longshore, so as to avoid the formation of shadow areas in the distribution of the sedimentary load transported by the watercourse. Although modest, the changes of the erosive trend that have been observed in the last eight years represent an important signal for the development of this territory. It will be necessary to monitor this coastal stretch with DGPS at high temporal resolution in order to understand whether this documented decrease will continue over time.

Future sporadic measurements of the solid load conducted near the river mouth during flood events could allow for calibration of the satellite observations (plume amplitude versus measured solid load data) to derive the solid load data directly from the study of satellite images, with considerable saving of time and money. A similar integrated approach could be easily used in other contexts affected by coastal erosion, where a holistic approach of this type could help identify unclear causes of erosion and support future development of these sensitive areas.

Supplementary Materials: The following are available online at https: / www.mdpi.com/2072-4 292/13/2/226/s1, Table S1: Table S1. Dataset of events between 100 and $700 \mathrm{~m}^{3} / \mathrm{s}$ and of events higher than $700 \mathrm{~m}^{3} / \mathrm{s}$. These data were extracted from the San Giovanni alla Vena time series ( https://www.sir.toscana.it/consistenza-rete) by identification of the peaks in the curve of daily discharge distribution.

Author Contributions: Conceptualization, M.B., N.C. and M.L.; methodology, M.B., M.L. and N.C. shoreline changes, discharge data M.L., M.B. Sentinel-2 data N.C.; formal analysis, M.B.; writing—original draft preparation, M.B.; writing—review and editing, M.B., M.L. and N.C.; funding acquisition, M.B. All authors have read and agreed to the published version of the manuscript. 
Funding: This research was funded by Pisa University, Fond Ateneo M. Bini and by the collaborative research agreement n. 579999-2019 "Autorità di Bacino Distrettuale Appennino Settentrionale" (Respp. Monica Bini and Roberto Giannecchini).

Institutional Review Board Statement: Not applicable.

Informed Consent Statement: Not applicable.

Data Availability Statement: Data available on request due to restrictions. The data presented in this study are available on request from the corresponding author. The data are not publicly available due to privacy reason and need of permission from local authorities. Most of data are available on the public URL of local authorities as reported in the text.

Acknowledgments: The authors are extremely grateful to the anonymous reviewers for their constructive comments and useful suggestions. The authors are also grateful to the "Provincia di Pisa Ufficio difesa del Suolo and Ufficio territoriale del Genio Civile del Valdarno inferiore" of the Tuscany Region for the availability of part of the DGPS data. The authors would also like to thank Nicola Del Seppia (Autorità di Bacino Distrettuale dell' Appennino Settentrionale) and Giovanni Zanchetta (Pisa University) for providing some data about the Arno River and for some useful discussions on the topic.

Conflicts of Interest: The authors declare no conflict of interest.

\section{References}

1. Lenôtre, N.; Thierry, P.; Batkowski, D.; Vermeersch, F. EUROSION Project The Coastal Erosion Layer. WP 2004, 2, 45.

2. Luijendijk, A.; Hagenaars, G.; Ranasinghe, R.; Baart, F.; Donchyts, G.; Aarninkhof, S. The state of the world's beaches. Sci. Rep. 2018, 8, 6641. [CrossRef]

3. IPCC. Global warming of $1.5^{\circ} \mathrm{C}$. In An IPCC Special Report on the Impacts of Global Warming of $1.5^{\circ} \mathrm{C}$ Above Pre-Industrial Levels and Related Global Greenhouse Gas Emission Pathways, in the Context of Strengthening the Global Response to the Threat of Climate Change, Sustainable Development, and Efforts to Eradicate Poverty; IPCC: Geneva, Switzerland, 2018.

4. Bird, E.C.F. Coastline Changes: A Global Review; Wiley: Chichester, UK; New York, NY, USA, 1985; ISBN 978-0-471-90646-9.

5. Mentaschi, L.; Vousdoukas, M.I.; Pekel, J.-F.; Voukouvalas, E.; Feyen, L. Global long-term observations of coastal erosion and accretion. Sci. Rep. 2018, 8, 12876. [CrossRef]

6. IPCC. Climate Change 2013 The Physical Science Basis; Stocker, T.F., Ed.; IPCC: Geneva, Switzerland, 2013.

7. Toimil, A.; Camus, P.; Losada, I.J.; Le Cozannet, G.; Nicholls, R.J.; Idier, D.; Maspataud, A. Climate change-driven coastal erosion modelling in temperate sandy beaches: Methods and uncertainty treatment. Earth Sci. Rev. 2020, 202, 103110. [CrossRef]

8. Besset, M.; Anthony, E.J.; Bouchette, F. Multi-decadal variations in delta shorelines and their relationship to river sediment supply: An assessment and review. Earth Sci. Rev. 2019, 193, 199-219. [CrossRef]

9. Anthony, E.J.; Marriner, N.; Morhange, C. Human influence and the changing geomorphology of Mediterranean deltas and coasts over the last 6000years: From progradation to destruction phase? Earth Sci. Rev. 2014, 139, 336-361. [CrossRef]

10. Anthony, E.J. Sand and gravel supply from rivers to coasts: A review from a Mediterranean perspective. Atti Soc. Toscana Sci. Nat. Mem. Ser. A 2018, 125, 13-33.

11. Anfuso, G.; Pranzini, E.; Vitale, G. An integrated approach to coastal erosion problems in northern Tuscany (Italy): Littoral morphological evolution and cell distribution. Geomorphology 2011, 129, 204-214. [CrossRef]

12. Blöschl, G.; Hall, J.; Viglione, A.; Perdigão, R.A.P.; Parajka, J.; Merz, B.; Lun, D.; Arheimer, B.; Aronica, G.T.; Bilibashi, A.; et al. Changing climate both increases and decreases European river floods. Nature 2019, 573, 108-111. [CrossRef]

13. Petropoulos, G.P.; Ireland, G.; Barrett, B. Surface soil moisture retrievals from remote sensing: Current status, products \& future trends. Phys. Chem. EarthParts A B C 2015, 83-84, 36-56.

14. Billi, P.; Fazzini, M. Global change and river flow in Italy. Glob. Planet. Chang. 2017, 155, 234-246. [CrossRef]

15. Degeai, J.-P.; Bertoncello, F.; Vacchi, M.; Augustin, L.; de Moya, A.; Ardito, L.; Devillers, B. A new interpolation method to measure delta evolution and sediment flux: Application to the late Holocene coastal plain of the Argens River in the western Mediterranean. Mar. Geol. 2020, 424, 106159. [CrossRef]

16. Pratellesi, M.; Ciavola, P.; Ivaldi, R.; Anthony, E.J.; Armaroli, C. River-mouth geomorphological changes over $>130$ years (1882-2014) in a small Mediterranean delta: Is the Magra delta reverting to an estuary? Mar. Geol. 2018, 403, 215-224. [CrossRef]

17. Ericson, J.; Vörösmarty, C.; Dingman, S.; Ward, L.; Meybeck, M. Effective sea-level rise and deltas: Causes of change and human dimension implications. Glob. Planet. Chang. 2006, 50, 63-82. [CrossRef]

18. Syvitski, J.P.M.; Kettner, A.J.; Overeem, I.; Hutton, E.W.H.; Hannon, M.T.; Brakenridge, G.R.; Day, J.; Vörösmarty, C.; Saito, Y.; Giosan, L.; et al. Sinking deltas due to human activities. Nat. Geosci. 2009, 2, 681-686. [CrossRef]

19. Tessler, Z.D.; Vörösmarty, C.J.; Grossberg, M.; Gladkova, I.; Aizenman, H. A global empirical typology of anthropogenic drivers of environmental change in deltas. Sustain. Sci. 2016, 11, 525-537. [CrossRef] 
20. Toniolo, A.R. Sulle Variazioni di Spiaggia a Foce d'Arno (Marina di Pisa) Dalla Fine del Secolo XViii ai Nostri Giorni: Studio Storico Fisiografico; Comune di Pisa, Ed.; Tipografia Municipale: Pisa, Italy, 1910.

21. Borgh, L. Apporto Allo Studio Sulle Cause di Variazione del Litorale Pisano; Comune di Pisa: Pisa, Italy, 1970.

22. Bini, M.; Casarosa, N.; Ribolini, A. L'evoluzione diacronica della linea di riva del litorale Pisano (1938-2004) sulla base del confront di immagini aeree georeferenziate. Atti Della Soc. Toscana Sci. Nat. Mem. Ser. A 2008, 113, 1-12.

23. Pozzebon, A.; Cappelli, I.; Mecocci, A.; Bertoni, D.; Sarti, G.; Alquini, F. A wireless sensor network for the real-time remote measurement of aeolian sand transport on sandy beaches and dunes. Sensors 2018, 18, 820. [CrossRef]

24. Besset, M.; Anthony, E.J.; Sabatier, F. River delta shoreline reworking and erosion in the Mediterranean and Black Seas: The potential roles of fluvial sediment starvation and other factors. Elem. Sci. Anthr. 2017, 5, 54. [CrossRef]

25. Grottoli, E.; Bertoni, D.; Pozzebon, A.; Ciavola, P. Influence of particle shape on pebble transport in a mixed sand and gravel beach during low energy conditions. Ocean Coast. Manag. 2019, 169, 171-181. [CrossRef]

26. Palla, B. Variazioni della linea di riva tra i Fiumi Arno e Serchio (Tenuta di S. Rossore-Pisa) dal 1878 al 1981 . Atti Soc. Tosc. Sci. Nat. Mem. Ser. A 1983, 90, 125-149.

27. Bertoni, D.; Mencaroni, M. Four different coastal settings within the northern Tuscany littoral cell: How did we get here? Atti Soc. Sci. Nat. Mem. Ser. A 2015, 125, 55-68.

28. Pranzini, E.; Anfuso, G.; Cinelli, I.; Piccardi, M.; Vitale, G. Shore protection structures increase and evolution on the Northern Tuscany Coast (Italy): Influence of tourism industry. Water 2018, 10, 1647. [CrossRef]

29. Federici, P.R.; Mazzanti, R. Note Sulle Pianure Costiere Della Toscana; Castiglioni, G.B., Federici, P.R., Eds.; Mem.Società Geografica Italiana: Roma, Italy, 1995; Volume 53, pp. 165-270.

30. Pranzini, E. Updrift river mouth migration on cuspate deltas: Two examples from the coast of Tuscany (Italy). Geomorphology 2001, 38, 125-132. [CrossRef]

31. Sarti, G.; Bini, M.; Giacomelli, S. The growth and the decline of Pisa (Tuscany, Italy) up to the Middle ages: Correlations with landscape and geology. Quat. Ital. J. Quat. Sci. 2010, 23, 311-322.

32. Bini, M.; Rossi, V.; Amorosi, A.; Pappalardo, M.; Sarti, G.; Noti, V.; Capitani, M.; Fabiani, F.; Gualandi, M.L. Palaeoenvironments and palaeotopography of a multilayered city during the Etruscan and Roman periods: Early interaction of fluvial processes and urban growth at Pisa (Tuscany, Italy). J. Archaeol. Sci. 2015, 59, 197-210. [CrossRef]

33. Cipriani, L.E.; Ferri, S.; Iannotta, P.; Paolieri, F.; Pranzini, E. Morfologia e dinamica dei sedimenti del litorale della Toscana settentrionale. Stud. Costieri 2001, 4, 119-156.

34. Casarosa, N. Studio dell' evoluzione del litorale pisano tramite rilievi con GPS differenziale (2008-2014). Stud. Costieri 2016, 23, 3-19.

35. Bertoni, D.; Sarti, G.; Alquini, F.; Ciccarelli, D. Implementing a coastal dune vulnerability index (CDVI) to support coastal management in different settings (Brazil and Italy). Ocean Coast. Manag. 2019, 180, 104916. [CrossRef]

36. Aminti, P.; Cammelli, C.; Cappietti, L.; Jackson, N.L.; Nordstrom, K.F.; Pranzini, E. Evaluation of beach response to submerged groin construction at marina di ronchi, Italy, using field data and a numerical simulation model. J. Coast. Res. 2004, 99-120.

37. Pranzini, E.; Simonetti, D. Influenza del fattore scala sulla classificazione delle spiagge in base alla loro tendenza evolutiva. Stud. Costieri 2008, 14, 13-28.

38. Bertoni, D.; Sarti, G.; Giuliano, B.; Pozzebon, A. In situ abrasion of marked pebbles on two coarse-clastic beaches (Marina di Pisa, Italy). Ital. J. Geosci. 2012, 131, 205-214.

39. Nordstrom, K.F.; Pranzini, E.; Jackson, N.L.; Coli, M. The marble beaches of Tuscany. Geogr. Rev. 2008, 98, 280-300. [CrossRef]

40. Van den Brink, H.W.; Können, G.P.; Opsteegh, J.D.; van Oldenborgh, G.J.; Burgers, G. Estimating return periods of extreme events from ECMWF seasonal forecast ensembles. Int. J. Clim. 2005, 25, 1345-1354. [CrossRef]

41. Pulido-Velazquez, M.; Peña-Haro, S.; García-Prats, A.; Mocholi-Almudever, A.F.; Henriquez-Dole, L.; Macian-Sorribes, H.; Lopez-Nicolas, A. Integrated assessment of the impact of climate and land use changes on groundwater quantity and quality in the Mancha Oriental system (Spain). Hydrol. Earth Syst. Sci. 2015, 19, 1677-1693. [CrossRef]

42. Merabtene, T.; Siddique, M.; Shanableh, A. Assessment of seasonal and annual rainfall trends and variability in Sharjah City, UAE. Adv. Meteorol. 2016, 2016, 6206238. [CrossRef]

43. Zhang, A.; Gao, R.; Wang, X.; Liu, T.; Fang, L. Historical trends in air temperature, precipitation. Water 2020, 12, 74. [CrossRef]

44. Dogliotti, A.I.; Ruddick, K.G.; Nechad, B.; Doxaran, D.; Knaeps, E. A single algorithm to retrieve turbidity from remotely-sensed data in all coastal and estuarine waters. Remote Sens. Environ. 2015, 156, 157-168. [CrossRef]

45. Bustamante, J.; Pacios, F.; Díaz-Delgado, R.; Aragonés, D. Predictive models of turbidity and water depth in the Doñana marshes using Landsat TM and ETM + images. J. Environ. Manag. 2009, 90, 2219-2225. [CrossRef]

46. Chen, Z.; Muller-Karger, F.E.; Hu, C. Remote sensing of water clarity in Tampa Bay. Remote Sens. Environ. 2007, 109, 249-259. [CrossRef]

47. Petus, C.; Chust, G.; Gohin, F.; Doxaran, D.; Froidefond, J.M.; Sagarminaga, Y. Estimating turbidity and total suspended matter in the Adour River plume (South Bay of Biscay) using MODIS 250-m imagery. Cont. Shelf Res. 2010, 30, 379-392. [CrossRef]

48. Blott, S.; Pye, K. GRADISTAT: A grain size distribution and statistics package for the analysis of unconsolidated sediments. Earth Surf. Process. Landf. 2001, 26, 1237-1248. [CrossRef]

49. Cappucci, S.; Bertoni, D.; Cipriani, L.E.; Boninsegni, G.; Sarti, G. Assessment of the Anthropogenic sediment budget of a littoral cell system (Northern Tuscany, Italy). Water 2020, 12, 3240. [CrossRef] 
50. Sarti, G.; Rossi, V.; Amorosi, A.; Bini, M.; Giacomelli, S.; Pappalardo, M.; Ribecai, C.; Ribolini, A.; Sammartino, I. Climatic signature of two mid-late Holocene fluvial incisions formed under sea-level highstand conditions (Pisa coastal plain, NW Tuscany, Italy). Palaeogeogr. Palaeoclim. Palaeoecol. 2015, 424, 183-195. [CrossRef]

51. Arno, B.d.F. Attività estrattive. In Supplemento Alla Gazzetta Ufficiale; Serie Generale n. 122; Gazzetta Ufficiale della Repubblica Italiana: Roma, Italy, 2000.

52. Billi, P.; Rinaldi, M. Human impact on sediment yield and channel dynamics in the Arno River Basin (central Italy). IAHS Publ. Ser. Proc. Rep. Intern Assoc Hydrol. Sci. 1997, 245, 301-311.

53. Cavazza, S. Regionalizzazione geomorfologica del trasporto solido in sospensione dei corsi d'acqua tra il magra e l'ombrone. Atti Della Soc. Toscana Sci. Nat. Mem. Ser. A 1984, 91, 119-132.

54. Paris, E.; Becchi, D. Il torso dell' Arno e la sua evoluzione storica. Acqua Aria 1989, 6, 645-652.

55. Paris, E.; Solari, L.; Bechi, G. Applicability of the de marchi hypothesis for side weir flow in the case of movable beds. J. Hydraul. Eng. 2012, 138, 653-656. [CrossRef]

56. Bellotti, P.; Calderoni, G.; Di Rita, F.; D’Orefice, M.; D’Amico, C.; Esu, D.; Magri, D.; Martinez, M.P.; Tortora, P.; Valeri, P. The Tiber river delta plain (central Italy): Coastal evolution and implications for the ancient Ostia Roman settlement. Holocene 2011, 21, 1105-1116. [CrossRef]

57. Pranzini, E. A model for cuspidate delta erosion. Coast. Zone 1989, 89, 4345-4357. 